\title{
Gentrifications in the Planetary Elsewhere: Tele-urbanization, Schengtrification, colour- splashing, and the mirage of "more-than-adequate" critical theory
}

Accepted version, published in Urban Geography 39 (10): 1455-1464.

DOI: $10.1080 / 02723638.2018 .1500248$

Web link to publisher version:

https://www.tandfonline.com/doi/full/10.1080/02723638.2018.1500248

\author{
Michael Gentile \\ Department of Sociology and Human Geography \\ University of Oslo \\ Postboks 1096 Blindern \\ 0317 Oslo, Norway \\ Tel. +47-22855150 \\ E-mail: michael.gentile@sosgeo.uio.no
}

\begin{abstract}
Despite the recent planetary turn that has swept through gentrification research, the theoretical barycentre remains pegged to a few strongholds located in the global north-west. Against this background, this essay offers a provincialized account of three gentrification-like trends - teleurbanization, Schengtrification and colour-splashing - which are currently taking place in Tbilisi, Riga and Kiev. It is proposed that these processes are supported by an underlying logic that is not pinned to these cities' specific ("post-communist") contexts, raising questions about the avowedly universal validity of theories of gentrification stemming from the global northwest, and particularly those developed within the more critical scholarly tradition.

Keywords: gentrification, tele-urbanization, Schengtrification, colour-splashing.
\end{abstract}

ACKNOWLEDGMENT: The author thanks Terje Wessel, Matthias Bernt, and two anonymous reviewers for their helpful comments on this text. 


\section{Gentrifications in the Planetary Elsewhere: Tele-urbanization, Schengtrification, colour- splashing, and the mirage of "more-than-adequate" critical theory}

\section{Michael Gentile (University of Oslo)}

Scholars of gentrification are increasingly willing to accept the postcolonial suggestion that gentrification theory stands on poorly fertilized empirical soil owing to its over-reliance on the experience of few, and uncharacteristic, cities in the global north-west (Lees 2012, Bernt 2016). Guided by theoretical advances within comparative urbanism, and facilitated by its conceptual pliability, gentrification is now being explored in a variety of contexts, adapting and stretching its definition to embrace the plurality of outcomes stemming from the intercourse of neoliberal urban regeneration policies (slum clearance, revitalization, renewal, smart growth, creative city, etc.) and local idiosyncrasies. The result is a recalibration of the geographies of gentrification research that moves the empirical barycenter towards the south-east and south-west (for an excellent overview, see Lees et al. $2015^{1}$ ). Yet, the theoretical barycenter is arguably less mobile, pegged as it is to the "backyards" of tonegiving scholars, who tend to apply existing theory, paying insufficient attention to contextual specifics and, above all, to alternative causal frameworks that may emerge when cities are allowed to speak out on their own terms (Smart and Smart 2017, see also Robinson 2005). This has led to a questioning of the overall heuristic capacities of the concept of gentrification (Maloutas 2012, Ghertner 2015), but it has also created new opportunities for its refinement in the light of the urban experience of the Planetary Elsewhere [e.g., Lemanski's (2014) work on "hybrid gentrification" in South Africa]. However, these opportunities are at odds with the desire held by some to pin down a theoretical core in gentrification, for a globally committed research agenda should take contextuality seriously, accepting that theoretical claims are best kept "light and revisable" rather than authoritative and universal (Robinson 2016a), and that context necessitates more than the mere theoretical sensitization to the local. Critical theory tends to treat contextuality as subordinate to a broader "context of context" (Brenner et al. 2011), or as the source of variation on the main theme of globalized neoliberalism. Thus, in refreshing the rent gap theory "in an era of planetary urbanization" (Slater 2017: 126), one of the most tone-giving critical scholars of gentrification suggests that our focus should be on the (planetarized) "cycles of building and destroying, of creating and tearing apart" (p. 128, cf. Brenner and Theodore 2002), and that we should therefore "jettison sub-disciplinary turf wars over how various parts of the world should be studied and theorized and consider instead the purchase and relevance of theories that have proven more than adequate (analytically and politically) in grasping the function of rent: to underpin investment and reinvestment opportunity, which in turn underpin uneven development under capitalism" (Slater 2017: 127-128, my emphasis). The superiority of global northwest-made (critical) theory could hardly be alleged more loudly. More-than-adequate theory comes from the global northwest: the rest is, at best, "context" - peripheral context, that is - in which the performance of supracontextual theories from the uncontextual centre is assessed and approved amidst a dazzling jungle of varieties of capitalism, neoliberalism, and other overarching structures of the global modus operandi. A more attractive approach, in my opinion, would be to jettison sub-disciplinary turf wars by revisiting and scaling-down the posited conceptual, theoretical, temporal and geographical reach of gentrification theory. Therefore, I agree with Smart and Smart (2017: 524) that we should "trim back the tendency to cover over local conceptual diversity" and "[treat] the invasive species of gentrification $[\ldots]$ as simply a topic of research, not as any kind of explanatory theory".

Without dipping into the dispute about the true essence of gentrification, and about how the process should be defined and delimited (see, e.g., Boddy 2007 vs. Davidson and Lees 2010), this short essay

\footnotetext{
${ }^{1}$ Tellingly, though, of the book's 20 case-based chapters, none explore the Central and Eastern European region.
} 
exploits the concept's recent amplification by discussing three urban gentrification-like trends that happen to be taking place across Central and Eastern Europe: "tele-urbanization", "Schengtrification" and "colour-splashing". It is argued that these three processes, while linked to certain characteristics of the region, are sustained by a broader underlying logic that is concealed by the over-reliance of critical scholarship on the aforementioned more-than-adequate theories of gentrification. Thus, taking inspiration in the recent calls for provincializing urban theory (Sheppard et al. 2013, Lawhon et al. 2016), and for "starting from anywhere" (Robinson 2016b), this contribution proposes that there remains much to be learned, and possibly some things to be unlearned, from the ordinary difference between the gentrifications present across the world. The "is this gentrification?" question will be intentionally downplayed - gentrification may or may not be a relevant construct depending on how wide a conceptual net is cast. At a bare minimum, however, tele-urbanization, Schengtrification and coloursplashing are related to the debates surrounding the current gentrification-gone-global (or planetary) paradigm, justifying their treatment with reference to them.

\section{Tele-urbanization}

Tele-urbanization is a remote-controlled urban transformation process in which diaspora capital occupies a more prominent position at the expense of "global" capital (Gentile et al. 2015). The concept puts especial emphasis on urbanization, rather than on the associated (possible) gentrification of the areas touched by it, primarily because it produces urban growth - but not necessarily population growth - rather than re-growth. In fact, tele-urbanization appears to take place in countries with relatively low urbanization levels and with substantial flows of diaspora capital and/or remittances (e.g., Georgia, Ecuador or Albania). In Georgia, the trend was particularly strong until the mid-2000s, when Georgians residing abroad, in Germany, in Russia, and in the US in particular, fueled a residential construction boom, particularly in the country's capital, Tbilisi (ibid.).

From the perspective of critical gentrification scholarship, tele-urbanization would seem to be one of the many ways through which planetary rent gaps are exploited and filled in, and in some cases, this may indeed be the case. The problem with this perspective is that tele-urbanization also occurs where rent gaps are not present, and where the prospect for making a profit from the associated investment is bleak. In the Sicilian province of Agrigento, for example, tele-urbanizing real estate investment, most of which informal, contributes to the largely uncontrolled growth of cities with declining populations and dwindling economic bases. The city of Palma di Montechiaro, for example, counts approximately 7,000 informal dwellings, but has a population of only about 23,000; furthermore, about 10,500 legalization requests were presented on the occasion of three waves of "condoni" (mass legalizations) in 1985, 1994, 2003 (Abbate 2009, based on figures from the Region of Sicily). Tele-urbanization has been taking place in this city for decades, supporting the local small-scale construction industry through what has been described as a "perverse and unstoppable mechanism that has produced an exaggerated quantity of almost entirely illegal new housing, lacking in any quality whatsoever, and remaining largely unused" (ibid., p. 152, author's translation). Indeed, under-occupancy is a recurrent problem of teleurbanization; in Ecuador, the problem is often referred to as one of "wasted housing" (Codesal 2014). Clearly, this type of tele-urbanization does not "gentrify", and no one gets displaced, but it does entail some of the negative effects of gentrification described in the literature, particularly as it erodes the assets of place for the city's de facto residents - what Davidson and Lees (2010) call displacement. More importantly, and from a more general perspective, it produces suboptimal "skeleton cityscapes" (Goodfellow 2017) that are not easy to correct once in place. On the other hand, it creates jobs that might not have existed otherwise (Codesal 2014).

Tele-urbanization in Georgia has more in common with newbuild gentrification than has the aforementioned Sicilian case, but it is not about luxury housing either. In fact, quite the contrary appears to be the case, as many of the buildings are poorly built with poor materials and obsolete technologies, but they nevertheless do represent a clear improvement in comparison with the standard 
Soviet-era apartment blocks. As a rule, the newbuilds occupy previously vacant or under-exploited land; in some cases, this has caused semi-coercive displacement, but this is the exception rather than the rule (Gentile et al. 2015).

Generally speaking, the intensity of new construction has been greatest in the city centre and in select right-bank parts of the city that have historically been the focus of prestige, but, echoing a notion that has become legion within critical gentrification scholarship, (newbuild) gentrification is no longer circumscribed to particular areas, but rather represents a wholesale colonization of urban space (cf. Davidson 2007). Yet, while very much is being built, like in Palma di Montechiaro, there are few colonists: in the evening, the lights are off in most of the apartments owned by diaspora Georgians. In other words, this looks like gentrification without gentrifiers: a transformation of the cityscape, and of the real estate market, that may indeed cause (mainly indirect) displacement, but where the most important impact is displacement. Even so, the fieldwork among local residents conducted by this author's team did not reveal much concern about the new developments (Gentile et al. 2015). In a society that is accustomed to rapid and unpredictable changes, including occasional wars, flash floods and revolutions, new condos are a less than alarming development.

Based on the above - allowing for a slight distortion of Neil Smith's (1979) oft rehearsed description of gentrification - the process may be viewed as a return to the city of capital, not people. Literally. Since gentrification involves gentrifiers, and not many of them actually exist in this case, it is perhaps more adequate to view Tbilisi's newbuild boom as a physical densification of the urban fabric, as a concentration of construction materials assembled in such a way as to enable its globally dispersed population to nurture a continued feeling of attachment to a stable dwelling "back home". For many, this might mean having a second home that is imagined as a primary residence. Some might return, at some point, possibly becoming gentrifiers. For others, an apartment in central Tbilisi may sustain the myth of return migration for a lifetime.

The newbuild transformations of Tbilisi's urban fabric probably represent the most striking impact on the city's physical and socio-spatial structure, but are they too unique to allow them to inform meaningful theorization? Are they perhaps little more than a regional trait, e.g., of the "post-socialist city", with little currency on the global market of urban theory? The answer is no. While teleurbanization does exhibit different results in different cities, its underlying logic is unbounded, but it is impossible to make sense of it with the "more-than-adequate" theories made in the global north-west (such as rent gap theory), nor is it easily framed within the fashionable discourse of planetary gentrification (López-Morales 2015, Lees et al. 2016). However, this unbounded logic could inform theory about, or at least complement the interpretation of, gentrification-like processes taking place elsewhere across the world, including in economically developed countries.

\section{Schengtrification}

"Schengtrification" - from the Schengen Agreement and gentrification - shares some similarities with tele-urbanization, because it involves real estate transactions where the "gentrifier" does not always show up. In Schengtrification, small- or mid-sized foreign capital is channeled into the property market of certain European cities, allowing investors to obtain coveted renewable 5-year residence permits allowing free movement across the Schengen area as a reward for their investment. The system was introduced in Latvia after its housing market collapsed in 2008, and while there are similar "golden visa" programmes in some other EU countries (Portugal, Greece and Hungary, for example), the required investment is much higher, and often contingent on investments within other spheres. In Latvia, the minimum required value threshold was initially very low, just $70000 \mathrm{EUR}$, but this was subsequently raised to the current level of 250000 EUR. Perhaps most importantly, physical presence in the country is not required. At this higher threshold, it can be assumed that most real estate transactions will have taken place within the central areas of Riga, the country's capital, as well as in the 
seaside resort of Jūrmala. The numbers are significant: in Latvia, the residence-by-real-estateinvestment program produced 13,518 new residents from its inception until the end of 2014, the vast majority of whom from Russia (Springe and Jemberga 2015). The number of applications from "Schentrifiers" rose dramatically following Russia's annexation of Crimea, but it appears to have slowed down recently because of the Russian economic decline and ruble devaluation, which may have an ungentrifying effect, and not just in Latvia. In either case, Riga's total population as of early 2015 was, by comparison, just 641000 . In other words, there are a lot of properties, most of which located within a limited area, that are bought up by people needing a residence permit allowing free travel within the Schengen area. Most of the buyers appear to belong to the Russian middle class, for whom this could be an emergency exit strategy, but there are outliers, such as a few of Putin's allies, as well as assorted oligarchs from Russia and, to a lesser extent from Ukraine and Uzbekistan (Springe and Jemberga 2015). Some are now on the EU individual sanctions list as a result of Russia's landgrab of Ukrainian territory and of its failure to respect the terms of the Minsk ceasefire agreements. By comparison, in the $\mathrm{UK}$, where residence-by-real-estate-investment is also a possibility, just 604 persons made use of this opportunity in 2014 (ibid. 2015). ${ }^{2}$

While the occurrence of Schengtrification in Latvia is connected to decisions related to the deep economic crisis that started in 2008, and to the country's geopolitical predicament, the underlying logic of Schengtrification, like that of tele-urbanization, is not pinned down to any particular context. Schengtrification is absentee gentrification that depends on the expanding freedom (of movement) gap between authoritarian states and democratic ones. Schentrifiers don't buy property; they buy freedom. The rent gap, on the other hand, plays the second fiddle of context. Because of the relatively high investment threshold required for obtaining a residence permit, Schentrifiers are not in the position to exploit existing rent gaps; they do not compete on the same market as the "regular" gentrifiers (who may, in turn, be of both local and foreign origin, the latter being the case for those not in need of a residence permit), and only a very small handful of them is endowed with the resources needed to "super-gentrify" (see Lees 2003).

\section{Colour-splashing}

Finally, "colour-splashing" is a peculiar form of (newbuild) gentrification that is currently transitioning to ubiquity in Kiev. It is best described by its reliance on an aesthetic that places colour before form and, arguably, ideology before function, quite unlike the globalized architectural uniformity that is often associated with newbuild developments located on former brownfields (see Airas 2016). Figure 1 reproduces a subway advertisement for "Comfort Town", the quintessential example of this trend, and an area that this author has been researching together with Kostyantyn Mezentsev, Nataliia Mezentseva and Iuliia Stebletska (Mezentsev et al., n.d.). Importantly, Comfort Town enacts a radical break with the stern monotony of the Soviet urban fabric of the city. ${ }^{4}$

Many newbuild developments in Kiev provide short-supplied modern residential space, often embroidered with lavish details and an eclectic but somewhat Donaldtrumpian mix of architectural and aesthetic influences favoured by the city's nouveau riche. While of a different quality and caliber - the quality not necessarily being higher - developments such as the one in the Obolon' neighbourhood (Figure 2) build on a tradition of ornamental excesses that certainly was not absent in the USSR. In fact, for the vast masses living in the dull spaces of the Soviet micro-districts, the architectural piquancy of the Stalinist-era buildings made them the ultimate mirage in the housing career of Homo Sovieticus. But

\footnotetext{
${ }^{2}$ This is not to be confused with the overall pattern of foreign ownership in the British real estate market, which is largely unrelated to the issue of obtaining a residence permit.

${ }^{3}$ I thank Kostyantyn Mezentsev for introducing me to this fascinating neighbourhood.

${ }^{4}$ Indeed, while it is a myth that the Great Wall of China can be seen from outer space, this author has been able to spot Comfort Town looking from an altitude of $234 \mathrm{~km}$ in Google Earth, which is not too far from the International Space Station.
} 
Comfort Town cannot be interpreted as a logical extension of this mirage, as a dream coming true. It is something else.

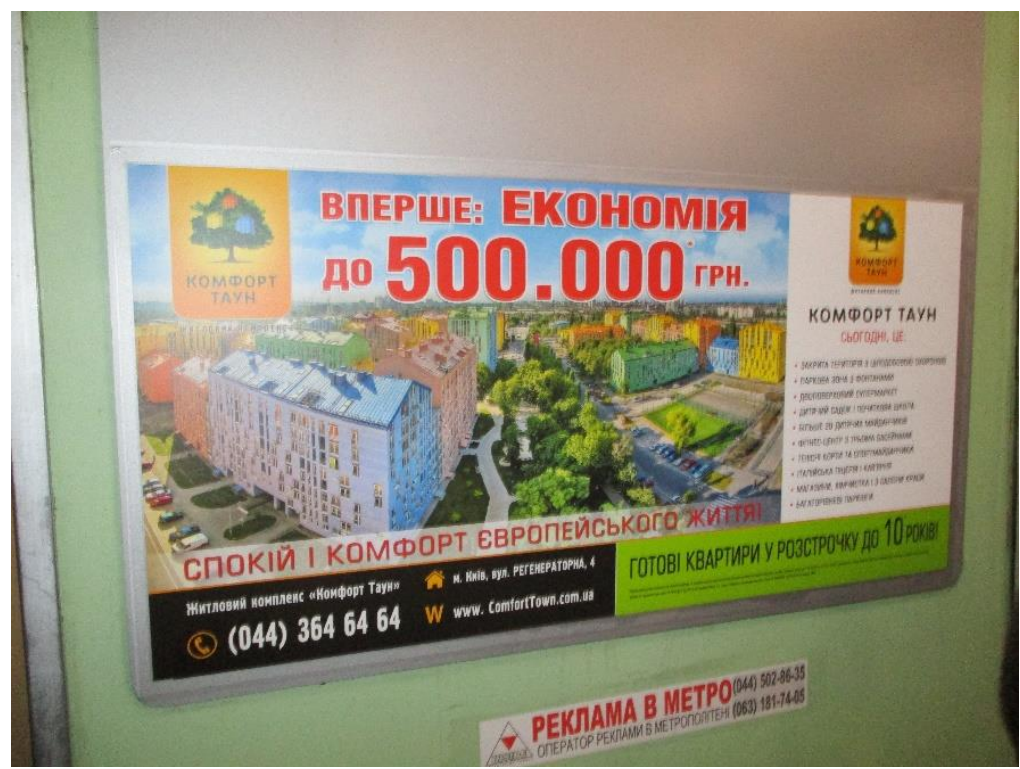

Figure 1

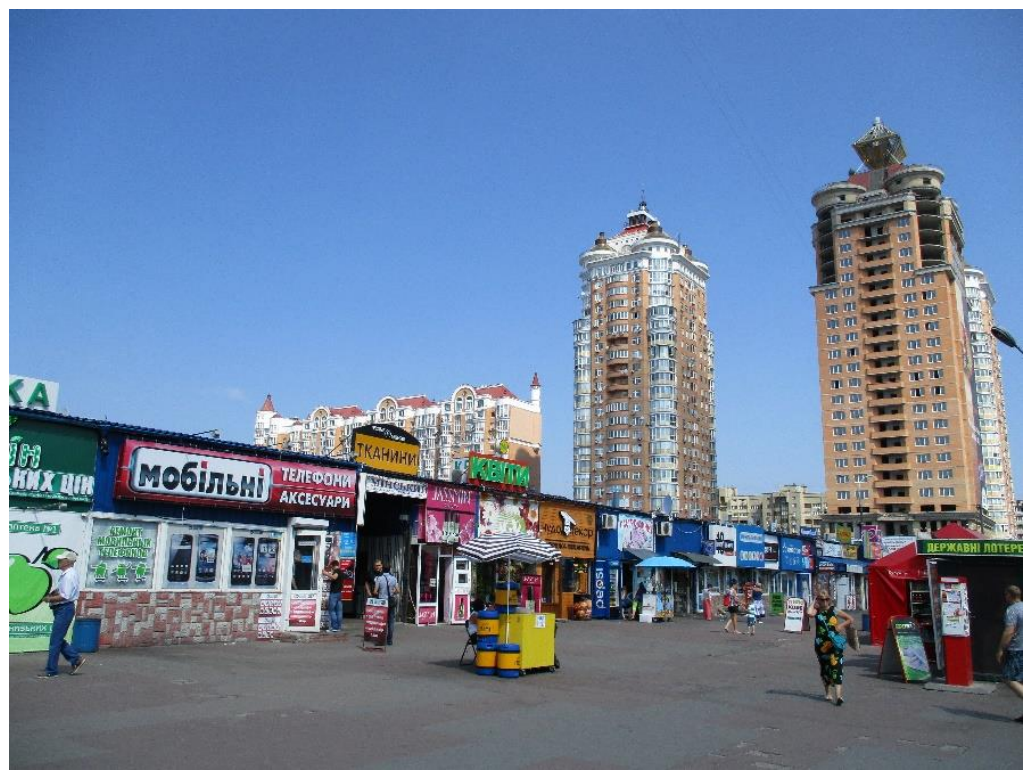

Figure 2

Although uncharacteristic in its colour scheme, on the surface, Comfort Town looks like an archetypal case of large-scale newbuild gentrification. It occupies a former brownfield site, it is surrounded by Soviet apartment blocks from the 1960's with generally impoverished residents, it is mostly inhabited by young and relatively affluent people and, last but not least, the entire area is porously gated porously, because the author repeatedly entered the compound bypassing its colander-quality security. Moreover, it is relatively poorly located, rather far from the city centre, and on the river Dnieper's less fashionable left bank. So, what sets Comfort Town, and similar projects across Ukraine, apart from newbuild gentrification as it is discussed in the literature? The answer is that Comfort Town fuses housing and ideology in a way that transcends the narratives of globalization and urbanity embedded in "Western" newbuild gentrification (see, e.g., Davidson 2007). Comfort Town represents a form of ideological gentrification in which the Soviet past is laid to rest. Specifically, the main storyline that appears on the development's website is the area's quixotic European theme: 
"We don't just sell apartments, we create a little Europe within the Ukrainian capital"

and

"One of Comfort Town's main landmarks is the big red windmill [...] The windmill is the symbol of the European concept around which Comfort Town was built" (http://comforttown.com.ua/, accessed 2 May 2018).

Rather than elitism and oligarch kitsch, the main brand of distinction that is sold in Comfort Town is thus a blend of ideology and naïveté centred on an imaginary - peaceful, but strikingly colourful Europe, a Europe surrounded by a dull, dangerous, anachronistic and easily Otherable Soviet swamp. This might not be so different from the global cosmopolitan lifestyle packages that are grafted onto the newbuild developments scattered along the river Thames (Davidson and Lees 2010), yet what is new is that the product is dependent on, and defined by, its immediate surroundings; without its gray Soviet encirclement, Comfort Town would rapidly drop its illusory Euro-appeal.

Summing up, to use Francis Fukuyama's famous disputed words, Comfort Town appears to be saying farewell to the last big competing ideology, embracing, as it were, the End of History (Fukuyama 1989), which "Europe" stands for, as opposed to the rest of Kiev, which is constructed as hopelessly Soviet. Even so, since the Euromaidan revolution more than four years ago, the colour splashing (and "colOthering") trend has spread across the city, accelerating the demise of history elsewhere too.

\section{Conclusion}

This contribution departed from three cities - Tbilisi, Riga and Kiev - located in the Planetary Elsewhere of urban knowledge, where they mainly and rarely fulfill the function of testing grounds for theories and concepts developed in the global northwest. Of course, it is ironic that it is sufficient to start from Europe's eighth largest city to offer a "provincialized" account of processes of urban change that are typically in sight from the academic belvedere of gentrification scholarship.

Indeed, from the latter vantage point, tele-urbanization, Schengtrification and colour-splashing may appear as local eccentricities, as capricious fruits of the interplay of unique geographical and historical circumstances. This short essay argued that these processes, whose outcomes deceptively resemble what proponents of global and planetary versions of gentrification would expect to find in the field, challenge the central assumption of critical gentrification theory, that of the centrality of the rent gap, be it planetary or street-block scaled. Instead, looking at tele-urbanization, Schengtrification and coloursplashing through the lens of theories on urban identities, and on the relation between ideology, geopolitical imaginaries, urban space, and its residents, could provide fertile new terrain for the conceptualization of gentrification, piercing through the mirage of "more-than-adequate" theory that continues to infest even the most prominent and nuanced critical analyses of gentrification.

\section{References}

Abbate, Giuseppe (2009). "Processi di Edificazione Abusiva nel Territorio di Agrigento: una Questione Irrisolta". In Francesco Lo Piccolo (ed.), Progettare le Identità del Territorio. Piani e Interventi per uno Sviluppo Locale Autosostenibile nel Paesaggio Agricolo della Valle dei Templi di Agrigento (pp. 145-164). Florence, Italy : Alinea Editrice.

Airas, Annika (2016). Historical distinctiveness in the changing built environment: Redevelopment of former woodworking waterfronts. Helsinki: Department of Geosciences and Geography.

Bernt, Matthias (2016). How post-socialist is gentrification? Observations in East Berlin and Saint Petersburg. Eurasian Geography and Economics, 57(4-5), 565-587. 
Brenner, Neil and Theodore, Nik (2002). Cities and the geographies of "actually existing neoliberalism". Antipode, 34(3), 349-379.

Brenner, Neil, Madden, David J. and Wachsmuth, David (2011). Assemblage urbanism and the challenges of critical urban theory. City, 15(2), 225-240.

Boddy, Martin (2007). Designer neighbourhoods: new-build residential development in nonmetropolitan UK cities-the case of Bristol. Environment and Planning A, 39(1), 86-105.

Codesal, Diana. M. (2014). From "mud houses" to "wasted houses": remittances and housing in rural highland Ecuador. REMHU: Revista Interdisciplinar Da Mobilidade Humana, 22(42), 263-280.

Davidson, Mark (2007). Gentrification as global habitat: a process of class formation or corporate creation?. Transactions of the Institute of British Geographers, 32(4), 490-506.

Davidson, Mark and Lees, Loretta (2010). New-build gentrification: its histories, trajectories, and critical geographies. Population, Space and Place, 16(5), 395-411.

Ferenčuhová, Slavomíra (2016). Accounts form behind the curtain: History and geography in the critical analysis of urban theory. International Journal of Urban and Regional Research, 40(1), 113-131.

Fukuyama, Francis (1989). The end of history?, The National Interest, 16 (Summer 1989), (3-18).

Gentile, Michael, Salukvadze, Joseph and Gogishvili, David (2015). Newbuild gentrification, teleurbanization and urban growth: Placing the cities of the post-communist south in the gentrification debate. Geografie 120(2): 134-163.

Ghertner, D. Asher (2015). Why gentrification theory fails in 'much of the world'. City, 19(4), 552-563.

Goodfellow, Tom (2017). Urban fortunes and skeleton cityscapes: real estate and late urbanization in Kigali and Addis Ababa. International Journal of Urban and Regional Research, 41(5), 786-803.

Springe, Inga and Jemberga, Sanita (2015), Latvia torn between money and fear of Russia, http://www.eurasianet.org/node/72166 (accessed 12 June 2017).

Lawhon, Mary, Silver, Jonathan, Ernstson, Henrik and Pierce, Joseph (2016). Unlearning (un)located ideas in the provincialization of urban theory. Regional Studies, 50(9), 1611-1622.

Lees, Loretta (2003). Super-gentrification: The case of Brooklyn Heights, New York city. Urban studies, 40(12), 2487-2509.

Lees, Loretta (2012): The geography of gentrification: Thinking through comparative urbanism. Progress in Human Geography, 36(2), 155-171.

Lees, Loretta, Shin, Hyun Bang and López-Morales, Ernesto (2015) (eds.). Global Gentrifications. Uneven development and displacement. Bristol and Chicago: Policy Press.

Lees, Loretta, Shin, Hyun Bang and López-Morales, Erenesto (2016). Planetary Gentrification. Chichester: John Wiley \& Sons.

Lemanski, Charlotte (2014). Hybrid gentrification in South Africa: Theorising across southern and northern cities. Urban Studies, 51(14), 2943-2960.

López-Morales, Ernesto (2015). Gentrification in the Global South. City, 19(4), 564-573.

Maloutas, Thomas (2012). Contextual diversity in gentrification research. Critical Sociology, 38(1), 33-48.

Mezentsev, Kostyantyn, Gentile, Michael, Mezentseva, Nataliia and Stebletska, Iuliia (n.d.). An island of civilization in a sea of delay? Indifference and fragmentation along the rugged shorelines of Kiev's newbuild archipelago, manuscript (copy may be supplied by author).

Robinson, Jennifer (2005), Urban geography: world cities, or a world of cities. Progress in Human Geography, 29(6), 757-765.

Robinson, Jennifer (2016a). Comparative urbanism: new geographies and cultures of theorizing the urban. International Journal of Urban and Regional Research, 40(1), 187-199.

Robinson, Jennifer (2016b). Starting from anywhere, making connections: globalizing urban theory. Eurasian Geography and Economics, 57(4-5), 643-657.

Sheppard, Eric, Leitner, Helga and Maringanti, Anant (2013). Provincializing global urbanism: a manifesto. Urban Geography, 34(7), 893-900.

Slater, Tom (2017). Planetary rent gaps. Antipode, 49(S1), 114-137. 
Smart, Alan and Smart, Josephine (2017). Ain't Talkin'Bout Gentrification: The Erasure of Alternative Idioms of Displacement Resulting from Anglo-American Academic Hegemony. International Journal of Urban and Regional Research, 41(3), 518-525.

Smith, Neil (1979). Toward a theory of gentrification a back to the city movement by capital, not people. Journal of the American Planning Association, 45(4), 538-548. 